\title{
PENGARUH IQ, EQ, OCB DAN SQ TERHADAP KINERJA PADA CIVITAS AKADEMIKA STIE ASIA MALANG
}

\author{
Wiwit Setyo Wardani ${ }^{1}$, Nunung Nurastuti Utami ${ }^{2}$ \\ 1,2STIE Malangkucecwara, Indonesia
}

INFO ARTIKEL

DOI: 10.32812/jibeka.v14i2.158

ISSN-P: 0126-1258

ISSN-E: 2620-875X

Keywords: Intellectual Intelligence, Emotional Intelligence, spiritual intelligence, Organizational Citizenship Behavior, Performance

Kata Kunci: Kecerdasan Intelektual, Kecerdasan emosional, kecerdasan spiritual, Organizational Citizenship Behavior, Kinerja

\begin{abstract}
Developments in the current era require companies to continue to develop and make appropriate strategic decisions. One strategic decision that must be appropriate is related to human resource development. One of the management developments is the management of human resources. One of them is in terms of intellectual intelligence, emotional intelligence, organizational citizenship behavior and spiritual intelligence on performance. This study aims to determine the effect of variables of intellectual intelligence, emotional intelligence, organizational citizenship behavior and spiritual intelligence on employee performance at the STIE ASIA Malang academic community. This study uses multiple linear regression analysis methods, validity test, reliability test, classic assumption test, and hypothesis testing and causal associative research types. Data collection using a questionnaire / questionnaire. The population in this study were all academics of STIE ASIA Malang. The results showed that: 1) intellectual intelligence influences performance 2) emotional intelligence influences performance 3) spiritual intelligence influences performance 4) organizational citizenship behavior (OCB) influences performance.
\end{abstract}

\section{ABSTRAK}

Perkembangan pada era saat ini, menuntut perusahaan untuk terus melakukan pengembangan dan pengambilan keputusan strategi yang tepat. Salah satu keputusan strategi yang harus tepat adalah terkait dengan pengembangan sumber daya manusia. Salah satu pengembangan manajemen adalah pengelolaan sumber daya manusia. Salah satunya ditinjau dari sisi kecerdasan intelektual, kecerdasan emosional, organizational citizenship behavior dan kecerdasan spiritual terhadap kinerja. Penelitian ini bertujuan untuk mengetahui pengaruh variabel kecerdasan intelektual, kecerdasan emosional, organizational citizenship behavior dan kecerdasan spiritual terhadap kinerja karyawan pada civitas akademika STIE ASIA Malang. Penelitian ini menggunakan metode analisis regresi linier berganda, uji validitas, uji reliabilitas, uji asumsi klasik, dan uji hipotesis dan jenis penelitian asosiatif kausal. Pengumpulan data dengan menggunakan angket / kuesioner. Populasi dalam penelitian ini adalah seluruh civitas akademika STIE ASIA Malang dan teknik sampling yang menggunakan rumus slovin. Hasil penelitian menunjukkan bahwa : 1) kecerdasan intelektual berpengaruh terhadap kinerja 2) kecerdasan emosional bepengaruh terhadap kinerja 3)kecerdasan spiritual berpengaruh terhadap kinerja 4) organizational citizenship behavior (OCB) berpengaruh terhadap kinerja. 


\section{Pendahuluan}

Perkembangan pada era saat ini, menuntut perusahaan untuk terus melakukan pengembangan dan pengambilan keputusan strategi yang tepat. Salah satu keputusan strategi yang harus tepat adalah terkait dengan pengembangan sumber daya manusia. Salah satu pengembangan manajemen adalah pengelolaan sumber daya manusia (Nurhayati, 2000:1). Manajemen perusahaan juga harus selalu memperhatikan kinerja karyawan dan faktor-faktor yang mempengaruhinya. Dengan mengetahui faktor-faktor tersebut, maka manajemen dapat meningkatkan kinerja karyawan sesuai harapan perusahaan. Hal yang perlu diperhatikan adalah bagaimana karyawan dalam mengelola diri sendiri dan membina hubungan dengan orang lain.

Kinerja adalah hasil kerja karyawan dilihat dari aspek kualitas, kuantitas, waktu kerja, dan kerjasama untuk mencapai tujuan yang telah ditetapkan organisasi (Sutrisno, 2010:172). Menurut Bangun (2012:234) standar pekerjaan dapat ditentukan dari isi suatu pekerjaan. Untuk memudahkan penilaian kinerja karyawan, standar pekerjaan harus diukur secara jelas melalui jumlah, kualitas, ketepatan waktu mengerjakan, kehadiran, dan kemampuan bekerja sama. Kinerja adalah suatu capaian yang diperoleh karyawan dalam melaksanakan tugasnya sesuai dengan tanggungjawabnya. Pencapaian kinerja perusahaan yang baik, dilihat dari kinerja yang telah dicapai karyawan. Kinerja merupakan perilaku nyata yang ditampilkan setiap orang sebagai prestasi kerja, sehingga perusahaan menuntut karyawannya mampu menampilkan kinerja yang baik (Yuniningsih, 2002; Rivai, 2006). Pengelolaan sumber daya manusia menjadi faktor utama dalam memastikan pencapaian kinerja yang baik.

Kecerdasan intelektual berpengaruh tinggi terhadap kinerja karyawan. Kecerdasan intelektual adalah kemampuan intelektual, analisa, logika, dan rasio. Kecerdasan intelektual merupakan kecerdasan untuk menerima, menyimpan, dan mengolah informasi menjadi fakta (Widodo, 2012:77). Seseorang yang memiliki kecerdasan intelektual tinggi, maka akan memiliki kinerja yang lebih baik. Penelitian Adjma dan Nasikin (2014), Putra dan Latrini (2016), Indriyani dan Utami (2018) menemukan bahwa kecerdasan intelektual berpengaruh terhadap kinerja karyawan. Kriteria dari kemampuan intelektual.

Kecerdasan emosional berpengaruh terhadap kinerja karyawan. Kecerdasan emosional adalah memberikan rasa empati, cinta, motivasi, dan kemampuan menanggapai kesedihan atau kegembiraan secara tepat (Zohar dan Marshall, 2007:3). Menurut Goleman (2005:43) kerangka kerja emosional terdiri dari kesadaran diri, pengaturan diri, motivasi diri, empati, dan keterampilan sosial. Hasil penelitian Bulan (2011), Sandiyah (2011), Trisnawati (2012), Adjma dan Nasikin (2014), Handayani, dkk (2014), Putra dan Latrini (2016), Indriyani dan Utami (2018) terdapat hubungan positif dan signifikan antara kecerdasan emosional dengan kinerja.

Kecerdasan spiritual merupakan faktor ketiga dalam penelitian ini yang berpengaruh terhadap kinerja karyawan. Sukidi (2002:94) mengemukakan bahwa nilai-nilai kecerdasan spiritual yang dibutuhkan dalam dunia kerja adalah kejujuran, keterbukaan, pengetahuan diri, fokus pada kontribusi, dan spiritual non dogmatis (fleksibel dan kesadaran tinggi). Mengacu pada teori motivasi yang dikemukakan Maslow (2009:2), kecerdasan spiritual terkait dengan aktualisasi diri atau pemenuhan tujuan hidup, yang merupakan tingkatan motivasi yang tertinggi. Kecerdasan spiritual yang tinggi ditandai dengan adanya pertumbuhan dan transformasi pada diri seseorang, tercapainya kehidupan yang berimbang antara karier/ pekerjaan dan pribadi/ keluarga, serta adanya perasaan suka cita serta puas yang diwujudkan dalam bentuk menghasilkan kontribusi yang positif dan berbagi kebahagiaan kepada lingkungan. Karyawan yang kecerdasan spiritualnya tinggi dan didukung lingkungan kerja yang juga spiritual, secara positif menjadi lebih kreatif, memiliki kepuasan kerja yang tinggi, mampu bekerja dengan baik secara tim, dan memiliki komitmen yang tinggi terhadap organisasi. Hasil temuan Tanuwijaya (2015), Putra dan Latrini (2016) terdapat pengaruh positif kecerdasan spiritual terhadap kinerja karyawan.

Organizational citizenship behavior (OCB) merupakan faktor keempat yang mempengaruhi kinerja dan sekaligus sebagai variabel keempat. Kecerdasan emosional dan 
kecerdasan spiritual yang ada pada diri seseorang maka sikap OCB yang diharapkan dalam suatu perusahaan ataupun organisasi sangat mungkin untuk diwujudkan. Individu (karyawan) akan dengan mudah memunculkan emosi positif untuk mencapai tujuan, meningkatkan kreativitas dan keterampilan dalam mengambil keputusan serta dapat mengubah penderitaan menjadi semangat (motivasi). Organizational Citizenship Behavior (OCB) adalah perilaku individu yang ekstra, yang tidak secara langsung atau eksplisit dapat dikenali dalam suatu sistem kerja yang formal, dan yang secara agregat mampu meningkatkan efektivitas fungsi organisasi (Organ, 2006). Civitas akademika STIE Asia telah menunjukkan perilaku yang menjurus pada Organizational Citizenship Behavior (OCB). Salah satunya yaitu sikap mendampingi tanpa diminta terlebih dahulu. Serta perilakuperilaku kooperatif dan saling membantu antar karyawan dan perilaku ini sangat penting bagi berfungsinya suatu organisasi.

Pengukuran kinerja karyawan sangat menarik untuk diteliti lebih lanjut. Peneliti belum menemukan penelitian tentang hubungan kecerdasan intelektual, kecerdasan emosional, kecerdasan spiritual, dan organizational citizenship behavior (OCB) terhadap kinerja karyawan dengan menggunakan objek perguruan tinggi, sehingga perlu dilakukan penelitian lebih lanjut. Sekolah Tinggi IImu Ekonomi merupakan perguruan tinggi yang terdiri dari dari dua program Strata-1 (S1) yaitu prodi akuntansi dan prodi manajemen, serta satu program Strata-2 (S2) prodi manajemen. Sekolah Tinggi IImu Ekonomi Asia menarik untuk dijadikan objek penelitian karena karyawan mempunyai banyak beragam mulai dari tingkat pendidikan, suku adat, dan agama.

\section{Gambar 1. Kerangka Konseptual}

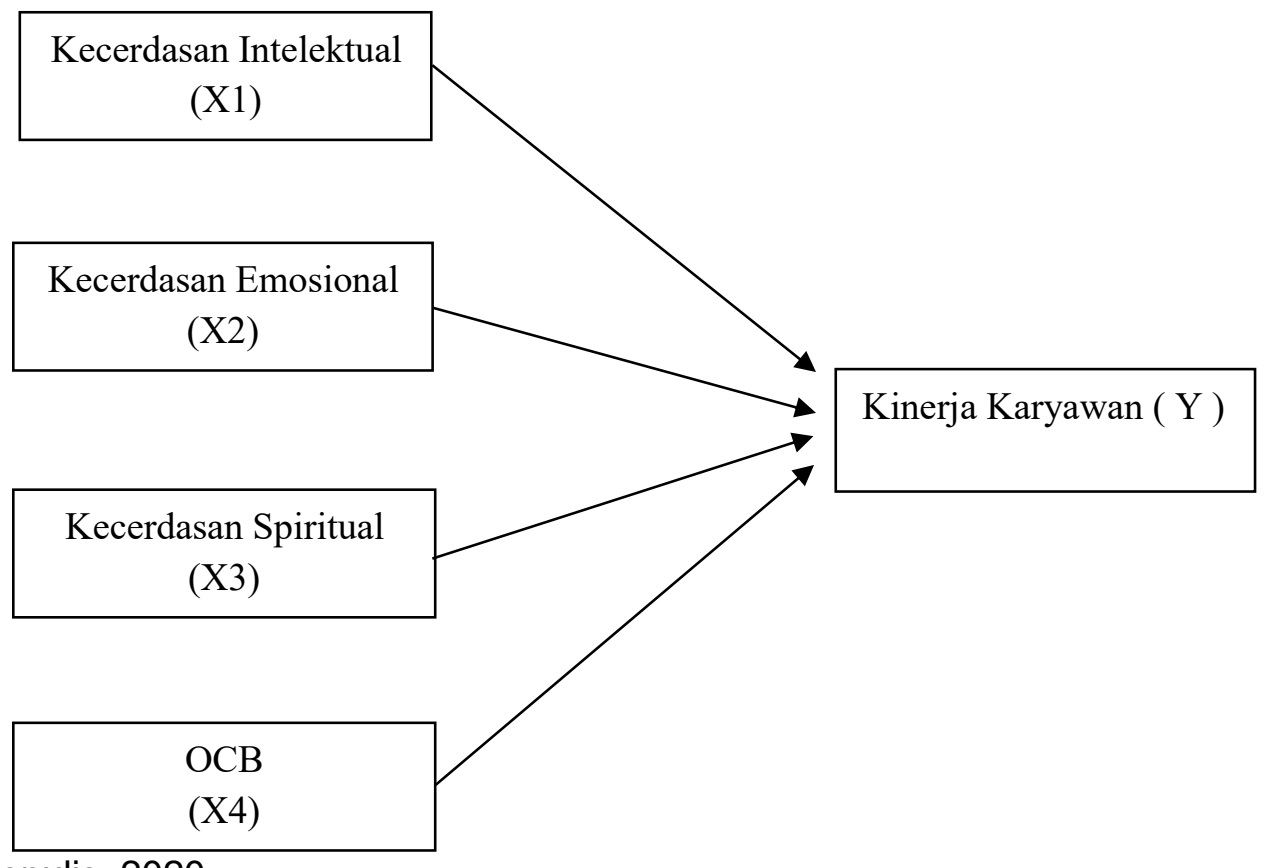

Sumber: Penulis, 2020

Tujuan dari penelitian ini dapat tergambar pada Kerangka Konseptual pada gambar 1 beserta hipotesisnya.

H1: Diduga Kecerdasan Intelektual berpengaruh positif terhadap Kinerja Karyawan pada Sekolah Tinggi Ilmu Ekonomi Asia Malang

$\mathrm{H} 2$ : Diduga Kecerdasan Emosional berpengaruh positif terhadap Kinerja Karyawan pada Sekolah Tinggi IImu Ekonomi Asia Malang

H3: Diduga Kecerdasan Spiritual berpengaruh positif terhadap Kinerja Karyawan pada Sekolah Tinggi Ilmu Ekonomi Asia Malang 
H4: Diduga Organizational Citizenship Behavior (OCB) berpengaruh positif terhadap Kinerja Karyawan pada Sekolah Tinggi Ilmu Ekonomi Asia Malang

\section{Metode Penelitian}

Jenis penelitian ini adalah penelitian asosiatif kausal. Penelitian asosiatif kausal adalah penelitian bertujuan untuk mengetahui pengaruh antar variabel (Bahri, 2018;18). mengetahui pengaruh antar variabel (Bahri, 2018;18).

Populasi adalah keseluruhan objek penelitian dan memenuhi karakteristik tertentu. Populasi penelitian adalah keseluruhan dosen dan karyawan STIE Asia Malang berjumlah 96 orang. Berikut adalah data dosen dan karyawan STIE Asia Malang. Dari populasi yang ada, ukuran sampel minimum diperoleh dengan menggunakan rumus slovin, di dapat 77 sampel.

\section{Hasil Penelitian dan Pembahasan}

Pada bagian ini akan dipaparkan hasil penelitian pengaruh kinerja kecerdasan intelektual, kecerdasan emosional, kecerdasan spritiual, dan organizational citizenship behavior (OCB) terhadap kinerja karyawan pada civitas akademika STIE Asia Malang.

1) Pengaruh kecerdasan intelektual terhadap Kinerja karyawan

Hasil pengujian hipotesis dengan uji-t menghasilkan b sebesar 0,149 (arah positif) dan signifikansi sebesar 0,047. Hasil pengujian ini menunjukkan nilai signifikansi $<0,05$ $(0,047<0,05)$, maka kecerdasan intelektual berpengauh terhadap Kinerja karyawan pada civitas akademika STIE ASIA Malang atau hipotesis pertama terbukti.

Pengaruh kecerdasan intelektual terhadap Kinerja karyawan Berdasar hasil pengujian hipotesis maka kecerdasan intelektual terhadap Kinerja karyawan pada civitas akademika STIE ASIA Malang berpengaruh atau H1 terbukti. Untuk membuktikan kemampuan karyawan maka seharusnya seorang karyawan harus mampu menunjukkan kecerdasan intelektual, yaitu dapat menggunakan nalarnya dengan berpikir logis. Choiriyah (2013) menyatakan bahwa kinerja yang baik tidak akan tercapai jika seorang karyawan tidak memiliki kemampuan berpikir yang benar (rasional dan kreatif). Seorang dengan kecerdasan intelektual dapat mengerjakan suatu tugas sesuai dengan aturan dan standar yang baik, seorang akan bekerja dengan IQ dan EQ bukan hanya sekedar dengan SOP akan lahir kerja yang sangat hati-hati dan teliti sehingga hasil kerja akan lebih baik.

Hasil penelitian mendukung temuan peneliti sebelumnya seperti Hanah (2019), Choiriyah (2013), Sina dan Noya (2012), Trihandini (2005), Armansyah (2002) Hunter (1996;450), Anastasi (1997;221), Moustafa dan Miller (2003;8). Terdapat korelasi antara kecerdasan intelektual dengan kinerja karyawan pada STIE Asia Malang disebabkan karena Civitas akademika sebagian besar adalah pendidik (dosen) sehingga kinerja karyawan selalu dibuktikan dengan kecerdasan intelektual.

2) Pengaruh kecerdasan emosional terhadap Kinerja karyawan

Hasil pengujian hipotesis dengan uji-t menghasilkan b sebesar 0,271 (arah positif), dan signifikansi sebesar 0,005. Hasil pengujian ini menunjukkan nilai signifikansi $<0,05$ $(0,005<0,05)$, maka kecerdasan emosional berpengaruh terhadap kinerja karyawan atau hipotesis kedua terbukti.

Hasil pengujian hipotesis menunjukkan kecerdasan emosional berpengaruh terhadap kinerja karyawan dan menunjukkan bahwa H2 terbukti. Hasil Penelitian menunjukkan bahwa kecerdasan emosional berpengaruh terhadap kinerja karyawan civitas akademika STIE Asia Malang. Hal ini menunjukkan bahwa kecerdasan emosional mampu meningkatkan kinerja karyawan. Karyawan yang mampu mengelola emosi dengan baik saat berhadapan langsung dengan mahasiswa maupun keluarga mahasiswa serta rekan kerja akan mampu melaksanakan pekerjaan dengan baik dan maksimal. 
Dalam hal pengendalian emosi, setiap hari kerja pasti dihadapkan dengan beban tugas dan semuanya harus dikerjakan sesuai prosedur dan seorang yang sedang emosional, tidak akan bisa berpikir dengan baik. EQ yang baik mempunyai kemampuan pribadi dan sosial seperti empati, disiplin diri, dan inisiatif sehingga akan menghasilkan kinerja yang lebih baik pula. Saat ini, di STIE Asia Malang telah menerapkan nilai-nilai untuk meningkatkan kinerja berupa pelayanan. Salah satunya yaitu mengutamakan kelulusan tepat waktu dengan penuh pelayanan kepada mahasiswa. Untuk mewujudkan hal tersebut maka civitas akademika harus memiliki kecerdasan emosional, sehingga mampu melaksanakan pekerjaan dengan baik dan maksimal.

Hasil temuan mendukung hasil penelitian Wibowo (2015), Jamal (2016), Rosdaranita (2017), Hanah (2019) yang juga menemukan bahwa kecerdasan emosional mempunyai pengaruh yang positif dan signifikan terhadap kinerja karyawan.

3) Pengaruh kecerdasan spiritual terhadap Kinerja karyawan

Hasil pengujian hipotesis dengan uji-t menghasilkan b sebesar $-0,200$ (arah negatif), dan signifikansi sebesar 0,024 . Hasil pengujian ini menunjukkan nilai signifikansi $<0,05$ $(0,024<0,05)$, maka kecerdasan spiritual berpengaruh terhadap kinerja karyawan atau hipotesis ketiga terbukti.

Hasil pengujian hipotesis menunjukkan kecerdasan spiritual berpengaruh terhadap kinerja karyawan pada civitas akademika STIE ASIA Malang. Tinggi rendahnya kecerdasan spiritual mempengaruhi kinerja civitas akademika STIE Asia Malang. Penelitian ini tidak sejalan dengan hasil penelitian Trisnawati (2012), Wibowo (2015), Hanah (2019) yang membuktikan bahwa kecerdasan spiritual tidak mempengaruhi kinerja karyawan.

4) Pengaruh organizational citizenship behavior (OCB) terhadap Kinerja karyawan

Hasil pengujian hipotesis dengan uji-t menghasilkan b sebesar 0,400 (arah positif) dan signifikansi sebesar 0,000 . Hasil pengujian ini menunjukkan nilai signifikansi $<0,05$ $(0,000<0,05)$, maka organizational citizenship behavior (OCB) berpengaruh terhadap kinerja karyawan pada civitas akademika STIE ASIA atau hipotesis keempat terbukti.

Hasil penelitian menunjukkan bahwa organizational citizenship behavior (OCB) berpengaruh terhadap kinerja karyawan. Hal ini menunjukkan bahwa organizational citizenship behavior (OCB) berpengaruh signifikan terhadap peningkatan kinerja civitas akademika STIE Asia Malang. OCB bersifat bebas dan sukarela, maka perilaku tersebut tidak diharuskan oleh persyaratan peran atau deskripsi jabatan yang secara jelas dituntut berdasarkan kontrak dengan organisasi sebagai pilihan personal.

Berdasarkan hasil penelitan menunjukkan bahwa organizational citizenship behavior (OCB) juga dibutuhkan dalam upaya untuk meningkatkan kinerja civitas akademika. Hal ini karena OCB merupakan salah satu perilaku yang harus dimiliki oleh civitas akademika dalam bekerja. Hasil penelitian mendukung temuan Kaori (2015) yang juga menemukan bahwa organizational citizenship behavior secara positif dan signifikan berpengaruh terhadap kinerja pada Civitas Akademika STIE Asia Malang.

Berdasarkan hasil penelitian menunjukkan bahwa kecerdasan intelektual berpengaruh terhadap kinerja civitas akademika STIE ASIA Malang. Hal ini menunjukkan bahwa kecerdasan intelektual mampu meningkatkan kinerja karyawan. Kinerja karyawan yang memiliki intelektual tinggi akan mampu melaksanakan pekerjaan dengan baik dan maksimal. STIE Asia telah berupaya untuk selalu meningkatkan intelektual dari seluruh civitas akademika STIE ASIA Malang melalui pelatihan dan pendidikan.

Kecerdasan emosional berpengaruh terhadap kinerja civitas akademika STIE ASIA Malang. Hak ini menunjukkan bahwa kecerdasan emosional mampu meningkatkan kinerja karyawan. Kinerja karyawan yang mampu mengelola emosi dengan baik saat berhadapan langsung dengan mahasiswa maupun rekan kerja akan mampu melaksanakan pekerjaan dengan baik dan maksimal. STIE Asia telah menerapkan nilai-nilai untuk meningkatkan kinerja. Salah satunya yaitu meningkatkan lulus tepat dan meningkatkan pelayanan khususnya pelayanan kepada mahasiswa. Untuk mewujudkan itu semua maka civitas 
akademika harus memiliki kecerdasan emosional, sehinnga mampu melaksanakan pekerjaan dengan baik dan maksimal.

Kecerdasan spiritual berpengaruh terhadap kinerja civitas akademika STIE ASIA Malang. Kecerdasan spiritual yang dimiliki oleh civitas akademika sangat penting dalam meningkatkan kinerja. Salah satu upaya yang dilakukan oleh STIE ASIA Malang dalam meningkatkan kecerdasan spiritual adalah dengan diadakannya kegiatan pengajian rutin disetiap minggunya. Hal ini terbukti dapat menigkatkan kinerja civitas akademika dengan signifikan. Civitas akademika dengan kecerdasan spiritual mampu mendorong dan mempengaruhi tujuan seseorang dalam mencapai karirnya di dunia kerja.

Berdasarkan hasil penelitian menunjukkan bahwa organizational citizenship behavior (OCB) berpengaruh terhadap kinerja civitas akademika STIE ASIA Malang. Organizational citizenship behavior (OCB) dibutuhkan dalam upaya untuk meningkatkan kinerja civitas akademika STIE ASIA Malang. OCB merupakan salah satu perilaku yang yang harus dimiliki oleh perawat dalam bekerja.

\section{Kesimpulan}

Berdasarkan hasil analisis yang telah dilakukan pada penelitian ini, maka dapat disimpulkan sebagai berikut:

1. Kecerdasan intelektual berpengaruh terhadap Kinerja karyawan pada civitas akademika STIE ASIA Malang.

2. Kecerdasan emosional berpengaruh terhadap kinerja karyawan pada civitas akademika STIE ASIA Malang.

3. Kecerdasan spiritual berpengaruh terhadap kinerja karyawan pada civitas akademika STIE ASIA Malang.

4. Organizational citizenship behavior (OCB) berpengaruh terhadap kinerja karyawan pada civitas akademika STIE ASIA Malang.

5. Civitas akademika STIE Asia Malang telah bekerja dengan IQ, EQ, SQ, dan OCB tidak hanya menciptkan kinerja yang baik tetapi juga mampu menciptakan rasa senang dan loyalitas yang tinggi.

Dengan hasi tersebut, peneliti menyarankan kepada peneliti selanjutnya mengembangkan objek penelitian sehingga hasil penelitian dapat digeneralisasi. Instrumen penelitian sebaiknya dilengkapi dengan wawancara sehingga hasil penelitian lebih lengkap dan mendalam.

\section{Daftar Pustaka}

Adjma, Djumarno, Nasikin. 2014. Analisis pengaruh kecerdasan intelektual, kecerdasan emosional, dan kecerdasan spiritual terhadap kinerja karyawan Pada PT Telkom Jakarta Selatan. Jakarta : Jurnal Manajemen Mutu. Vol. 13 No. 1. Hal 32-39

Asmadi Didi, Bambang Syairudin Erwin Widodo. 2015. Kontribusi Kecerdasan Emosional dan Kecerdasan Spiritual terhadap Kinerja Karyawan yang Dimoderasi Kepemimpinan Transformasional Surabaya: Prosiding Seminar Nasional Manajemen Teknologi XXII.

Edwardin, L.T.A.S. 2006. Analisis Pengaruh Kompetensi Komunikasi, Kecerdasan Emosional, Dan Budaya Organisasi Terhadap Kinerja Karyawan. Tesis tidak dipublikasikan. Semarang : Magister Manajemen Universitas Diponegoro.

Goleman, D. 2007. Emotinal Intelligence: Kecerdasan Emosional. Mengapa El lebih Penting daripada Iq. Jakarta: Gramedia Pustaka Utama. 
Indriyani, Desty Sesiana dan Hamidah Nayati Utami. 2018. Pengaruh kecerdasan emosional dan kecerdasan spiritual Terhadap kinerja karyawan (studi pada karyawan pt industri kereta api (persero) madiun - jawa timur. Madiun: Jurnal Administrasi Bisnis (JAB). Vol 59 No1

Kaori Kin Mineke Res, Sri Wahyuni, Lely Hana, dan Chairul Saleh.2015. Pengaruh Kecerdasan Spiritual Terhadap Kinerja Pelayanan Melalui Organizational Citizenship Behavior ( OCB ) Pada PT. PLN Persero Area Jember. Jember: Fakultas Ekonomi Universitas Jember

Pasek, Nyoman Suadnyana, A.A. N. B. Dwirandra dan I. G. A. Made Asri Dwija Putri. 2015. Pengaruh kecerdasan intelektual pada pemahaman Akuntansi dengan kecerdasan emosi dan kecerdasan Spiritual sebagai variabel pemoderasi. Bali: E-Jurnal Ekonomi dan Bisnis. Universitas Udayana 4.102015 : 703-714

Prihono, I Ketut Budiartha, dan Ida Bagus Putra Astika. 2016. Pengaruh motivasi, budaya organisasi dan Spiritualitas pada kinerja pegawai kantor pelayanan Perbendaharaan negara di provinsi bali. Bali: E-Jurnal Ekonomi dan Bisnis. Universitas Udayana 5.7 (2016): 2063-2090

Putra, Kadek Agus Santika dan Made Yenni. 2016. Pengaruh kecerdasan intelektual, kecerdasan emosional, kecerdasan spiritual, komitmen organisasi terhadap kinerja auditor. Bali: E-Jurnal Akuntansi. Universitas Udayana Vol.17.2. November 2016: 1168-1195.

Sri Langgeng Ratnasari. 2015. Pengaruh kecerdasan intelektual, kecerdasan emosional dan kecerdasan spiritual terhadap kinerja Staff departemen quality assurance PT. PEB BATAM. Seminar and Call For Paper.

Reza, S. Dan S.T. Hananto. 2004. Pengaruh Emotional Quotient Auditor terhadap Kinerja Auditor di Kantor Akuntan Publik. Jurnal Perspektif Vol 9, No1

Tanuwijaya, Ronald. 2015. Pengaruh Spiritual Leadership dan Kepuasan Kerja Terhadap Kinerja Karyawan pada PT. Sari Pawita Pratama. Agora. Vol 3 No 1. Hal 504-509.

Fernanda Yudha Tiara dan Ni Wayan Sukmawati Puspitadewi.Tanpa Tahun. Hubungan Antara Kecerdasan Emosional dengan Organizational Citizenship Behavior Pada Karyawan PT. X Surabaya. Surabaya: Universitas Negeri Surabaya Jurnal Psikologi

Nielsen M. Tjai, George A. Hrivnak, dan Megan Shaw Tanpa Tahun. OCB and Performance: A Group-Level Meta-Analytic Review. Washington : George Washington University

Titisari Purnami. 2014. Peranan Organizational Citizenship Behavior ( OCB ) dalam Meningkatkan Kinerja Karyawan. Jakarta : Mitra Wacana Media

Trihandini, R.A.F.M, 2005. Analisis Pengaruh Kecerdasan Intelektual, Kecerdasan Horison, Dan Kecerdasan Spiritual Terhadap Kinerja (Studi Kasus Pada Hotel Horison Semarang). Tesis, Tidak dipublikasikan. Semarang: Magister Manajemen Universitas Diponegoro. 